\section{Ikke helt på bølgelengde}

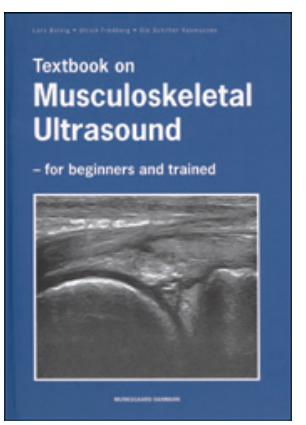

Lars Bolvig, Ulrich Fredberg,

Ole Schifter Rasmussen

Textbook on musculoskeletal ultrasound

210 s, ill. København: Munksgaard Danmark,

2011. Pris DKK 378

ISBN 978-87-6280-824-9

Ultralyd er i dag etablert som diagnostisk metode for patologier i muskel- og skjelettsystemet. Metoden var opprinnelig forbeholdt radiologene, men brukes i økende grad av revmatologer, fysikalskmedisinere og ortopeder som en utvidelse av den kliniske undersøkelsen. Grundig teoretisk og praktisk opplæring under veiledning er en forutsetning for å kunne ta metoden i bruk. I tillegg vil de fleste trenge et oppslagsverk for den daglige bruken. I denne boken prøver forfatterne å dekke dette behovet, men klarer det bare delvis.

I den korte innledningen diskuterer forfatterne muligheter og begrensninger i forhold til diagnostisk ultralyd. Den følges av en generell del om ultralydteori. I tredje del, som er hoveddelen, blir ultralyddiagnostikk av spesifikke organområder og vevstyper gjennomgått. Sonografiske standardprojeksjoner og eksempler på normale og patologiske funn blir presentert. Forfatterne gjør dette på en oversiktlig måte, hvor pasientens posisjonering og transducerens plassering vises ved siden av det respektive ultralydbildet. Normalfunnene er merket med blå ramme, patologiske funn med rød ramme. Bildekvaliteten er bra, og eksemplene er instruktive.

Men boken har en rekke mangler. I presentasjonen av de forskjellige bruksområdene skiller forfatterne ikke mellom områder hvor metoden har vist seg å være meget bra, f.eks. ved rotatorcuffruptur, og områder hvor den er for dårlig sammenliknet med alternative metoder, f.eks. ved meniskskader. Her mangler det viktig kommentering og veiledning. Dette kunne man ha gjort med henvisning til videreførende litteratur, som dessverre er helt utelatt. Forfatterne har heller ikke funnet plass til et kapittel om ultralydveiledede intervensjoner. Injeksjon med målrettet applikasjon av diagnostiske eller terapeutiske substanser under ultralydkontroll er et viktig felt, og mangelen på en innføring vil fort bli savnet av leseren. En viktig fordel med ultralyd er at det er mulig å undersøke muskel- og skjelettsystemet i bevegelse, såkalt dynamisk ultralyd. Hvorfor ledsages boken ikke av en CD som viser dette viktige aspektet av metoden? Manglende opplysninger om forfatternes faglige bakgrunn, mangelen på et stikkordregister og en noe kjedelig innpakning trekker ytterligere ned.

Jeg mener at boken kan fungere bra som et lite atlas til jevnlig oppdatering, men sammenliknet med andre publikasjoner i dette fagfeltet er den ikke mitt førstevalg.

\section{Stefan Moosmayer}

Ortopedisk avdeling

Martina Hansens hospital

\section{Hva er kirurgisk kunnskap?}

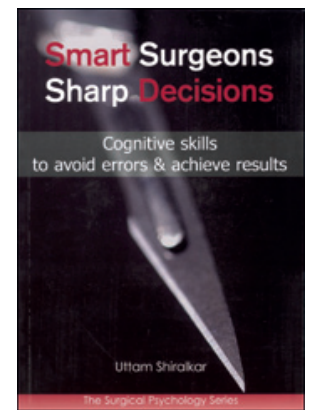

\section{Uttam Shiralkar Smart surgeons - sharp decisions}

Cognitive skills to avoid errors and achieve results. 136 s, ill. Shrewsbury: TFM

Publishing, 2011. Pris GBP 28

ISBN 978-1-903378-81-6
Denne boken har et allmenngyldig innhold, men er spesielt rettet mot kirurger. Forfatteren er en omskolert kirurg, som nå jobber som psykolog. Han søker å bevisstgjøre de mekanismene som leder mot de gode eller dårlige avgjørelsene i klinisk arbeid, og hvordan beslutninger tas. For å parafrasere teksten: En kirurg var misfornøyd med hvordan beskjeder ble gitt på operasjonsstuen og kalte til seg operasjonssykepleieren, ba henne lese på dørskiltet hva som sto der, hvorpå hun leste hans navn. Kirurgen sa at hun hadde gått glipp av det viktigste poenget, for bak navnet hans sto det MD (medical doctor) «and it stands for «Makes Decision»»", noe som gjorde ham til kirurg. Han gjorde det klart for henne hvem som ga ordrer og tok avgjørelser i systemet.

God kirurgi handler $95 \%$ om å treffe avgjørelser. Resten er avhengig av kirurgisk teknikk. På doktorskolen lærer man lite om hvordan man faktisk treffer gode avgjørelser, dette blir heller ikke undervist i spesialistutdanningen. Likevel må man som kliniker og kirurg treffe et hundretalls avgjørelser hver dag. De er ofte ikke basert på lærebøker, harde fakta eller eksakt tilgjengelig informasjon, men på magefølelse og intuisjon. I denne utgivelsen tar man for seg disse «myke» aspektene som er med på å avgjøre hvordan vi velger i det daglige - hvordan erfaring, følelser, underbevissthet og forventninger er med på å forme vår kliniske kunnskap. Ofte referert til som legekunst, er det disse faktorene som gjerne skiller en god fra en dårlig avgjørelse. Likevel er det en del mekanismer som man kan bli bevisst på.

Boken er delt inn i en rekke kapitler med kasuistikker og delte erfaringer, og forfatteren tar for seg den menneskelige faktoren, pasientsikkerhet og hvorfor gode kirurger tar dårlige avgjørelser. Boken er tidsriktig, og tematikken er aktuell (1). Den er ikke akademisk belastet og tung, men skrevet slik at faktisk også medisinstudenter vil ha glede av å lese den. Teksten er tydelig med en nesten muntlig fortellerstil og ikke lang. Forfatteren setter søkelyset på en del kanskje selvsagte ting som man vil kjenne igjen som erfaringsbasert kunnskap, magefølelse og intuisjon, men er like fullt nyttig og lettlest stoff.

Som kirurg er man alltid en del av et team med medspillere. Kirurgen «MD» nevnt ovenfor fikk besøk av operasjonssykepleieren dagen etterpå - hun ville forklare hvorfor ikke alltid ordrene hans ble utført, og ba ham lese på navneskiltet hennes. Han leste navnet hennes etterfulgt av forkortelsen RN (registered nurse). «Ja», sa sykepleieren, «det betyr nemlig «Reject Nonsense»». Boken anbefales.

\section{Kjetil Søreide}

Kirurgisk avdeling

Stavanger universitetssjukehus

Litteratur

1. Gruen RL, Watters DA, Hollands MJ. Surgical wisdom. Br J Surg 2011 doi:10.1002/bjs.7688. 